\title{
What Advertising Can Teach Us About Effective Writing and Speaking
}

\author{
COMMUNICATION CORNER No. 39
}

\author{
by Philip Yaffe
}

\section{Editor's Introduction}

Each "Communication Corner" essay is self-contained; however, they build on each other. For best results, before reading this essay and doing the exercise, go to the first essay "How an Ugly Duckling Became a Swan," then read each succeeding essay.

As a form of writing, advertising copy has a poor reputation because in many minds its objective is to "sell people things they don't want and don't need." This is debatable. What is not debatable is that advertising copy represents some of the best writing you will ever see. It has to, because its objective is to say a world of things in just a thimble-full of words. Writers of more meritorious texts (articles, essays, book reports, business reports, research papers, etc.) can learn a lot from understanding how these consummate wordsmiths go about their work. 


\title{
What Advertising Can Teach Us About Effective Writing and Speaking
}

\author{
COMMUNICATION CORNER No. 39
}

\section{by Philip Yaffe}

"I know that half the money I spend on advertising is wasted. The problem is, I don't know which half."

This succinct resume of the advertiser's dilemma is often attributed to John Wanamaker (18381922), the department store pioneer. Some people prefer to give the credit to Henry Ford (18631947), the automobile pioneer, or other favorite business giants. Whoever said it first, it is certain that it has been said thousands of times since.

The significance of the observation is nothing short of astounding. These are people whose business is investing and harvesting financial assets, yet when it comes to advertising, they freely admit to wasting at least 50 percent of their money.

Fortunately, we have moved on considerably in the century or so since the statement was first uttered, in large measure thanks to John Caples' book Tested Advertising Methods, first published in 1932 and endlessly reprinted ever since.

It is called Tested Advertising Methods because over a 50-year period Mr. Caples actually conducted scientific experiments to find out what really works ... and what doesn't. Some of his findings are surprising and in fact explode a number of myths about advertising.

Don't be fooled by the fact that the book is "decades out of date." Its findings are based on fundamental human nature, which has not fundamentally changed in millennia, so it is hardly likely to have fundamentally changed in less than a century. Because they are fundamental, in addition to advertising, many of Mr. Caples' findings also apply to communication (writing and speaking) in general.

Because it was first published in 1932, the book is largely concerned with print advertising, i.e. what you would find in newspapers and magazines. Let's examine some of the myths and misconceptions about advertising Mr. Caple revealed by looking at a summary of the book's key advice:

- What you say is more important than how you say it 
- $\quad$ The headline is the most important element in most ads

- $\quad$ The most effective headlines appeal to the reader's self-interest

- Long headlines that say something are more effective than short headlines that say nothing

- $\quad$ Long body copy sells more than short body copy

Some of these points may surprise you or puzzle you. So let's look at them one at a time.

\section{What you say is more important than how you say it}

In other words, elegant writing that might impress a literary critic is of no value. Your objective is to be clear. If you can be clear and elegant, wonderful. But first and foremost, be clear.

\section{The headline is the most important element in most ads}

Of course we all know this, but perhaps not for the reason many people might think. The principal function of the headline-and the illustration, and all the other elements of the ad-are to get people to read the body copy. A clever headline that is admired for itself but fails to bring readers into the body copy is of no value.

\section{The most effective headlines appeal to the reader's self-interest}

This is hardly surprising. Whenever we are enjoined to make an effort (i.e. read an ad), we almost always ask ourselves, consciously or subconsciously, "What's in it for me?" It follows that a headline that answers this question is more likely to attract readers than one that doesn't.

\section{Long headlines that say something are more effective than short headlines that say nothing}

I would like to examine this bit of advice for a moment because it is an area of advertising about which I have frequently had long, loud discussions.

On one occasion, I wrote a headline that contained three key sales arguments, but it was 11 words long. The client told me that I must shorten it because it was "too long." I had spent considerable effort trying to find a way of putting three key sales arguments into only 11 words. I therefore didn't take this criticism very well. After a long, heated discussion, the client agreed to keep the headline, as well as a number of other controversial aspects of the ad, exactly as they were.

The result: Sales of the product increased 40 percent over the following year. This was in an industry where sales increases of 5-10 percent for this type of product would have already been considered a major achievement. 


\section{Long body copy sells more than short body copy}

I would also like to examine this bit of advice in some detail because in my career it has also frequently led to long, loud discussions.

How many times have you heard it said, "Keep body copy short. Most people don't read body copy anyhow." As we have already noted, the objective of the ad is to get people to read the body copy, because this is where you really sell the product.

Let me propose an analogy. Suppose you are a door-to-door salesman. Your job is to go up and down the street knocking on each door to try to sell a vacuum cleaner. You know before you start that only one person in $\mathbf{2 0}$ is likely to have any interest in buying a vacuum cleaner.

What do you do when you find this one person? If you are a good salesperson, you go into the house, demonstrate the apparatus, and give as much information as possible in order to make the sale. What you don't do is hand the person your business card and say, "This is the address of my shop in the center of town. Come visit me and I will show you my vacuum cleaners."

An advertisement works the same way. Maybe only one person in 20 has any fundamental interest in your product. But once that interest is aroused (the role of the headline), that is the time to make the sale (the role of the body copy). If the body copy does not provide sufficient information to hold that reader's interest, they turn the page and the sale is lost.

Here is a practical method for determining the appropriate length of body copy. Although it is easy to state, it requires considerable judgment to apply.

If the body copy contains one word more than needed to deliver its message, then it is probably too long. If it contains one word less than needed to deliver the message, it is definitely too short!

In summary, when writing a text or preparing a speech, remember:

- Always start off with something that will quickly grab your audience's attention. This is usually best done by appealing to their self-interest. That is, the introduction quickly answers the question "What's in it for me?"

- Make certain that everything you subsequently write or say is designed to keep answering that question. Avoid introducing elements that are simply interesting or cute. What you think is interesting or cute might not be so interesting or cute to your audience. Stick to the script. 


\begin{abstract}
About the Author
Philip Yaffe was born in Boston, Massachusetts, in 1942 and grew up in Los Angeles, where he graduated from the University of California with a degree in mathematics and physics. In his senior year, he was also editor-in-chief of the Daily Bruin, UCLA's daily student newspaper. He has more than 40 years of experience in journalism and international marketing communication. At various points in his career, he has been a teacher of journalism, a reporter/feature writer with The Wall Street Journal, an account executive with a major international press relations agency, European marketing communication director with two major international companies, and a founding partner of a specialized marketing communication agency in Brussels, Belgium, where he has lived since 1974. He is the author of more than 30 books, which can be found easily in Amazon Kindle.
\end{abstract}

DOI: $10.1145 / 3492344$ 